\title{
Empowering Women Ex-Migrant Workers and Domestic Violence Victims through Komunitas Perempuan Singkong Jaya
}

\section{Pemberdayaan Perempuan Purna Pekerja Migran dan Korban Kekerasan dalam Rumah Tangga pada Komunitas Perempuan Singkong Jaya}

\author{
Anif Fatma Chawa ${ }^{1 *}$, Arief Budi Nugroho, Dhanny Septimawan Sutopo \\ ${ }^{1}$ Department of Sociology at Faculty of Social and Political Science, Universitas Brawijaya, Kota Malang, 65145, Indonesia \\ *) Corresponding author: anif_chawa@ub.ac.id
}

\begin{abstract}
This article seeks to understand the empowerment of women ex-migrant workers who have faced various problems before, during and after going back to the homeland as ex-migrant workers. These problems include unemployment, family's affairs, exploitation, discrimination and domestic violence. Komunitas Perempuan Singkong Jaya has been established to carry out empowerment programs to overcome these problems. The purpose of this study is to identify the needs as well as the problems that hinder the implementation of the programs and seeks to find the solutions. This study employs descriptive qualitative approach to examine the implementation of the development programs which have been conducted by Komunitas Perempuan Singkong Jaya located in Desa Sukowilangun, Kec. Kalipare, Kab. Malang. Based on the findings, there are several problems in the implementation of development programs, including the lack of capital and facilities, packaging and marketing, as well as product license problems. Addressing these problems, some intervention programs have been conducted, including training and funding which have generated intended outputs. However, this study also found that the change in lifestyle of these women ex-migrant workers has resulted in their being reluctant to be involved in the development programs.
\end{abstract}

Keywords: Empowerment, Migrant Worker, Women.

\section{ABSTRAK}

Artikel ini bertujuan untuk memahami proses pemberdayaan pada perempuan purna pekerja migran yang menghadapi berbagai masalah baik sebelum, selama dan setelah berhenti menjadi pekerja migran dan kembali ke kampung halaman. Beberapa masalah tersebut diantaranya adalah pengangguran, masalah keluarga, eksploitasi, diskriminasi dan kekerasan dalam rumah tangga. Komunitas Perempuan Singkong Jaya dibentuk salah satu diantaranya bertujuan untuk mengatasi berbagai masalah tersebut melalui berbagai program pemberdayaan. Tujuan penelitian ini dilakukan adalah untuk mengidentifikasi kebutuhan dan masalah yang ditemukan dalam program pemberdayaan serta sekaligus mencari solusi atau jalan keluar untuk mengatasinya. Studi ini menggunakan pendekatan kualitatif deskriptif untuk mengkaji program pemberdayaan program yang dilakukan oleh Komunitas Perempuan Singkong Jaya yang berada di Desa Sukowilangun, Kec. Kalipare, Kab. Malang. Berdasarkan penelitian, ada beberapa masalah yg ditemukan yaitu diantaranya adalah kurangnya fasilitas dan modal, pengemasan dan pemasaran produk dan ijin atau sertifikat pemasaran. Untuk mengatasi permasalah tersebut, penelitian ini melakukan program intervensi termasuk pendampingan, pelatihan dan pendanaan yang memiliki dampak positif pada program pemberdayaan. Tetapi, temuan data dari penelitian juga menunjukan bahwa perubahan gaya hidup dari perempuan purna pekerja migran menyebabkan mereka enggan untuk berpartisipasi dalam program-program pemberdayaan.

Kata kunci: Pemberdayaan, Pekerja Migran, Perempuan

Content from this work may be used under the terms of theCreative Commons Attribution-ShareAlike 4.0 International. Any further distributionof this work must maintain attribution to the author(s) and the title of the work, journal citation and DOI.

Published under Department of Communication and Community Development Science, IPB University and in association with Ikatan Sosiologi Indonesia

E-ISSN: 2302-7525 | P-ISSN: 2302-7157 


\section{INTRODUCTION}

Migrant workers have been challenged by various risks including exploitation and discrimination (Raharto \& Noveria, 2012). Despite this fact, becoming migrant workers is a dream of most people in Indonesia who live in poverty. They assume that becoming migrant workers is an easy and effective way to alleviate their poverty. Several factors that encourage people to go overseas as a migrant worker are poverty and lack of infrastructure such as education, health and job opportunities(Siegel \& Waidler, 2012). Until May 2019, there were 1.598.522 migrant workers from Indonesia who were working in several countries including Hongkong, Malaysia, Saudi Arabia and Taiwan (Febrinastri \& Hapsari, 2019).

Unfortunately, besides the success stories of migrant workers, these workers have faced several potential problems including exploitation during the working period in destination countries, in the recruitment process in the country of origin and repatriation, human trafficking and have been neglected to get their wages (Dewi, 2019; Koser \& Laczko, 2010; Raharto \& Noveria, 2012). Moreover, women migrant workers are more vulnerable to exploitation and violation of their rights due to the culture and nature of their work, the lack of skills and education; the lack of migrants'/prospective migrants' knowledge of the legal processes of recruitment and placement of labors to work overseas; the involvement of brokers in the recruitment and placement processes; the lack of national legal instruments related to the protection of women migrant workers; and the lack of commitment of the Indonesian government to ratify international legal instruments concerning the protection of migrant workers, regardless of race or class, gender or nature of their work (Raharto \& Noveria, 2012).

Various community development and advocacy programs have been conducted to address the problem of women migrant workers. The objective of these programs is to empower migrant workers in order to build their capacity to overcome those issues including poverty traps, health, legal issues, discrimination, exploitation and violence (Abas, Widyahseno, \& Rudianto, 2016; Assumptah \& Suharko, 2016; Raharto \& Noveria, 2012; Sitepu, 2011; Wijayanigtyas, 2016). The word empowerment always goes hand in hand with the concept of power. Therefore, many scholars defined empowerment and related it with the concept of power. Rowland (1997) in Rahman (2013) explained that there are different forms of power. First is power over (controlling power), this may be responded to by compliance, resistance (which weakens the process of victimization) or manipulation. Second is power to (generative or productive power), this sometimes incorporates or manifests as a form of resistance or manipulation which creates new possibilities and actions without domination. Third is power with, 'a sense of the whole being greater than the sum of individuals, especially when group overcomes problem together'. Fourth is power within, 'the spiritual strength and uniqueness that resides in each one of us and makes humans human. The basis is self-acceptance and self-respect, which in turn, to respect and accept others equally'.

The concept of women empowerment is always related to gender relations between women and men. Gender inequality is a product of the power relationships that exist between women and men in society(Rahman, 2013). This inequality is considered as the main factor causing various issues faced by women including stigma, discrimination, marginalization and violence, both as households as well as migrant workers. One of the solutions to overcome this gender inequality is by conducting women empowerment (Backhans, Lundberg, \& Månsdotter, 2007). Kabeer (2003) stated that women empowerment must be built based on the concept of power from within. Kabeer continued to explain that this kind of empowerment requires increasing women's capacity to be able to control resources, to determine agendas and make decisions in ways that women could have self-respect, sense of agency and awareness to recognize issues related to subordination and how it is maintained. Moreover, Batliwala (1993) in Rahman (2013) stated that empowerment is about changing the balance of power (redistribution of power) in a given society. Power is defined as control over resources (physical, human, intellectual, financial, self-esteem, self-confidence and creativity) and ideology (beliefs, values, attitudes, values, ways of thinking and perceiving situations). Another definition, Hasin, Hasan, \& Musa (2018) stated that 'women empowerment is the procedure in which women achieve increased control and involvement in decision making which ultimately helps to attain an equal foundation with men in various spheres - social, cultural, economic, political and civic'. Sushama (1998) stated that women empowerment is a situation in which women are given the opportunity to participate fully in the field of social, political and economic life. It can be 
concluded that women empowerment is a process to build women's skills and capacity in order to actively participate (have power) in decision making, take control over resources and ideology, increase self-agency and self-awareness which lead to transformation in every aspect, social, politics, and economic as well as free from any forms of subordination and discrimination.

Specifically, this study is concerned with women empowerment, particularly in economic aspect. Elliott (2008) in Maunere and Phiri (2018) defined the economic empowerment as a process of according to which women have the power to become "bread winners" to be self-reliant to generate income from projects and fight poverty. This process, for instance, is to provide women acces to land, credit market and labour opportunities (Morrison \& Biehl, 2007). Furthermore, Hasin, Hasan, $\&$ Musa (2018) stated that 'economic empowerment of women leads to development of family and community, which means enabling equal access to knowledge, resources and monetary prosperity for women and increasing their creativity'. Hasin, Hasan, \& Musa (2018) continued to explain that the sustainability of economic development at individual and household level will require greater access and control over women through physical, financial assets and properties. It can be argued that to attain economic improvement in the household, community and even greater society, it should be initiated by empowering women.

Women empowerment can be achieved by establishing community development program, including the one that has been conducted on women ex-migrant workers. In addition, there were numerous studies that have been conducted to examine the implementation of these development programs in various perspectives including sociology, economy, health, law, organization, communication and gender (Munawaroh, 2019; Nursalam, Yusuf, Widyawati, \& Asmoro, 2015; Octaviani, 2015; Raharto \& Noveria, 2012; Sulaiman, Sugito, \& Sabiq, 2017; Supriana \& Nasution, 2010). These studies have also proposed various models and solutions to the problems in which development programs could be implemented effectively to achieve their empowerment objective.

This study is concerned with the same issue as the prior studies which is to examine the implementation of community development programs on the women ex-migrant workers as well as finding solutions to the problems of these programs. It should be underlined that this study goes beyond those previous research studies which mostly only promoted academic models of the implementation of the development programs. This study is not only concerned with how the development programs have been conducted but also with direct contribution or intervention by finding solutions to the problems which hampered the implementation. Therefore, this study promotes an applicable model of how the implementation of community development programs could achieve the empowerment objectives. This study has also provided a comprehensive assistance to women ex-migrant workers, so they could carry out their development programs independently and increase their livelihood income.

This study depicts the community development programs which have been conducted by Komunitas Perempuan Singkong Jaya. This group is a women organization which involves women ex-migrant workers and domestic violence victims in Desa Sukowilangun as members. The objective of these development programs is not only to attain the economic empowerment of the members but also to overcome psychological issues they have faced. This study is the second study that sets two objectives: first, conducting a need assessment to identify several problems which hamper the economic empowerment process and secondly finding solutions to address those problems. Economic empowerment has been assumed to increase the wealth of women ex-migrant workers as well as their families in order to release them from the poverty issues and domestic violence. Related to gender equality, this empowerment process would involve a redistribution of power, particularly within households in Desa Sukowilangun. The first study has already been conducted to identify the social and economic condition of women ex-migrant workers and their families using survey method (Chawa, Al Yusainy, Adila, \& Kusumastuti, 2018).

\section{METHOD}

In this study, qualitative descriptive approach was employed, which is a comprehensive summary, in everyday terms, of specific events experienced by individuals or groups of individuals (Bungin, 2010; Lambert \& Lambert, 2013). Moreover, Sandelowski (2000) explained that a qualitative descriptive design facilitates "a comprehensive summary of an event in the everyday terms of those events". This 
study was conducted to describe and make a comprehensive summary of the social and economic lives of women ex-migrant workers and their families di Desa Sukowilangun as well as to examine how they have been empowered by Komunitas Perempuan Singkong Jaya.

This study utilized a purposive strategy that allowed researcher to utilize their specific knowledge or expertise about some groups to select informants (van den Berg, 2010). Therefore, in this study the informants were selected based on certain criteria including their knowledge, their involvement and their responsibility related to the development programs of Komunitas Perempuan Singkong Jaya. These informants included the head and members of this organization, about fifty housewives who were ex-migrant workers and domestic violence victims aged 30 years and over. This organization has been established in Desa Sukowilangun, Kecamatan Kalipare, Kabupaten Malang. This village is a remote area that lacks various public infrastructures and services, such as education, markets and employment. As a result, most people in Desa Sukowilangun live in poverty and go overseas to become migrant workers to overcome this problem. There are several countries which become destination countries of migrant workers from Desa Sukowilangun, for instance, Hongkong, Singapore, Malaysia and Taiwan. Apart from the poverty issue, women ex-migrant workers also experience violence issue, not only from their employers when they become migrant workers but also domestic violence from their husband.

Data of this study was collected from three methods including semi-structured interview as the main source of information, observation and documents. 'The semi-structured format allows people to answer more on their own terms than the standardized interview permits, but still provides a greater structure for comparability over that of the focused or unstructured interview (May, 2011). This method was used to collect data related to the implementation of development programs which have been conducted by Komunitas Perempuan Singkong Jaya, for instance the kinds of program, the problems and solutions to overcome the problems. This study employed observation to obtain data from its natural setting that was studied including the physical data of the poor migrant workers that can be observed such as their houses. Documents was also important source of this study to collect various data including journal articles and secondary data from Komunitas Perempuan Singkong Jaya as well as from Desa Sukowilangun.

\section{RESULTS AND DISCUSSION}

\section{Social and economic condition of women ex-migrant workers}

This study was divided into three stages: first, identifying social, psychological and economic issues of women ex-migrant workers; second, doing need assessment to examine the problems that hinder the implementation of the development programs; and third, finding solution to overcome them. The first stage was conducted in the previous research that shows the social and economic condition of exmigrant workers and their family by employing three variables, namely income, expenditure and education level (Chawa et al., 2018)

This current study found that the families of women ex-migrant workers in Desa Sukowilangun lived in poverty as traditional peasants with small production and agricultural workers (landless peasants). As a result, they lived in what Scott stated as the line of subsistence economy, which means that peasant household could provide their income from rice paddy field production only for survival including meeting consumption needs, paying rent and taxes, conducting ceremonial obligations, production costs and so forth (Haggis, Jarrett, Taylor, \& Mayer, 1986; Scott, 1976). No rice paddy production could be provided commercially to increase surplus income. In order to survive, the exmigrant worker families have other jobs as their second occupation, such as catching fish from the river, gardening, raising cows or goats, working in the forest cutting wood and going to fulfill their basic needs. It was very rare for poor families to go outside Desa Sukowilangun to look for other occupations due to the fact that geographically this village is located in a remote area in the middle of Jati (teak) forest.

Because of poverty issues and lack of infrastructure, most people in Desa Sukowilangun, including women ex-migrant worker and their family have a low-level formal education as illustrated in Figure 1 below: 


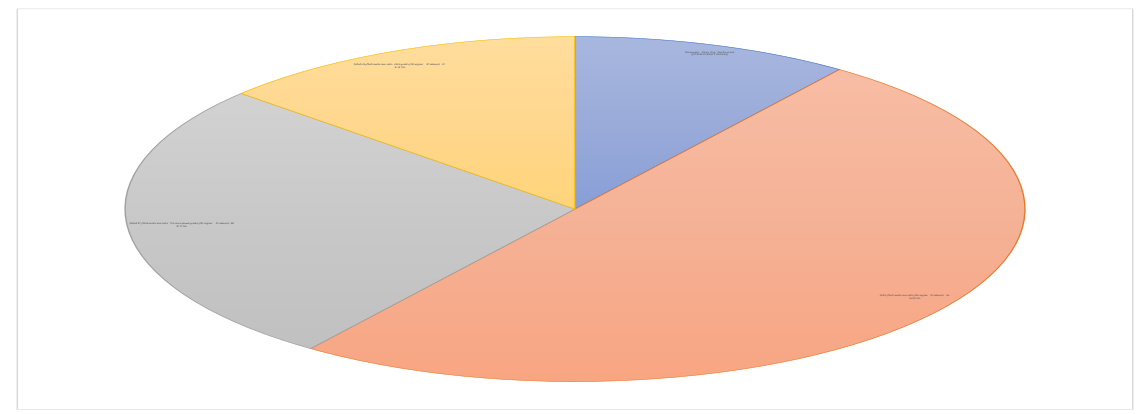

Figure 1. Education Level of Ex-Migrant Workers' Families in Desa Sukowilangun

Figure 1 illustrates that most of ex-migrant workers' families have a low-level formal education, where $10 \%$ have never attended school and 50\% have only completed SD (Sekolah Dasar or primary high school). Meanwhile other family members completed higher level of education, $27 \%$ completed SMP (Sekolah Menengah Pertama or junior high school) and 13\% completed SMA (Sekolah Menengah Atas or Senior High School). As a consequence, there was lack of employment in Desa Sukowilangun, as illustrated in Figure 2 as follows:

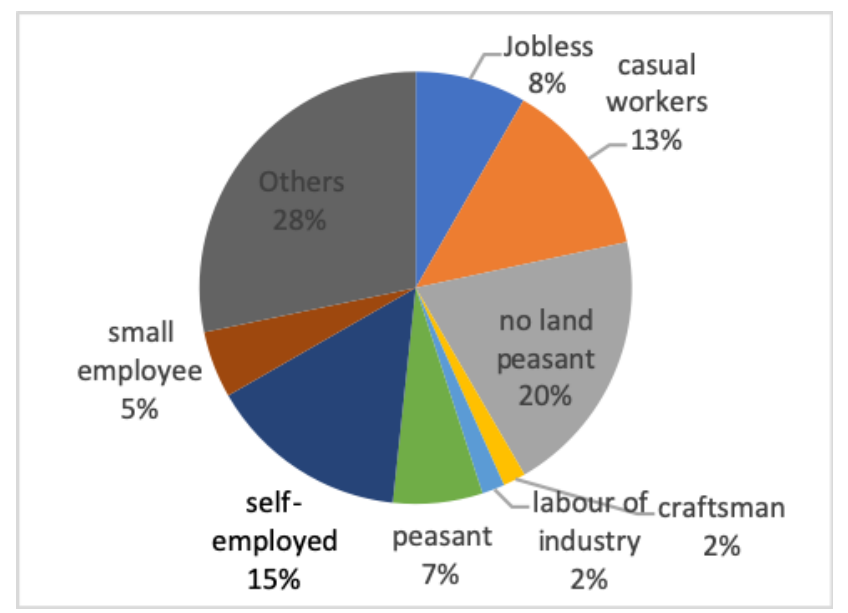

Figure 2. The Employment in di Desa Sukowilangun Source: fieldwork data

Figure 2 illustrates the various kinds of job or occupations which have been provided in Desa Sukowilangun. Most of these jobs do not require particular skills and high-level formal education including landless peasants, peasants, craftsman, self-employers, industrial workers, drivers and casual workers. This has caused many people in Desa Sukowilangun decided to go overseas to become migrant workers. They assumed that becoming migrant workers is the only way to overcome their debt and other economic issues. As a result, since 1980 there have been many poor people in Desa Sukowilangun, so most women become domestic migrant workers in several countries including Egypt, Malaysia, Hongkong, Taiwan, Singapore and South Korea.

Unfortunately, since 2010 many women migrant workers have been repatriated back to Desa Sukowilangun, particularly women aged between 50 years and over. Their employers assumed that the migrant workers at this age could no longer be productive. The migrant workers who are already in Desa Wilangun have been challenged again by the same problem, namely poverty problems. Many women ex-migrant workers become unemployed because they do not have skills and appropriate education; besides there is a lack of employment in Desa Sukowilangun. This makes it difficult for these women to get new occupations. Moreover, these migrant workers have faced various family problems including divorce, juvenile delinquency, consumptive life style and domestic violence, as illustrated in this interview: 
...they compete in everything.... trying to be the best...buying clothes, cars, houses, handphones.... I'm very sad to see that (Bu Sri: the leader of Komunitas Perempuan Singkong Jaya)

.....ex-migrant workers find it difficult to adapt....they forget that they live in poverty again... when they became migrant workers they had a lot of money...could build luxurious houses and bought cars.... (Bu Yuni: a member of Komunitas Perempuan Singkong Jaya)

The change in lifestyle was primarily influenced by increased income when they became migrant workers. Some of these migrant workers made adjustment by changing their consumption pattern. They tend to be more consumptive-oriented by buying or consuming goods only for prestige reasons, such as buying luxurious cars, instead of fulfilling their basic needs. The migrant workers still have this new lifestyle, even when they have returned to Desa Sukowilangun as ex-migrant workers. Moreover, the ex-migrant workers are also challenged by other family problems including juvenile delinquency, as illustrated in the following interview excerpt:

...... when their mother was away and the children were left behind in this village...these children lived with their father or grandparent.... as a result they felt free to do anything they wanted...sometimes they did bad thing for instance drug abuse and alcohol addiction and free sex.....(Bu Sri: the leader of Komunitas Perempuan Singkong Jaya)

Women ex-migrant workers in Desa Sukowilangun should face their family problems related to their children. The children of migrant workers were usually left behind to live with their father or extended family members, for instance grandparents and uncles or aunts. As a consequence, there was limited control on the behavior of the children or teenagers, particularly in relation to access to online information via the internet, such as social media and YouTube which have been deemed responsible for causing various bad behavior of those teenagers including drug abuse, free sex, as well as alcohol and porn addiction.

Other crucial issues which have been faced by women ex-migrant workers in Desa Sukowilangun are psychological issues. Many of these ex-migrant workers have had experienced domestic violence from their employers when they became domestic migrant workers. Moreover, other ex-migrant workers have had domestic violence experience from their husbands.

The complex problems of women ex-migrant workers in Desa Sukowilangun have challenged Bu Sri to find a solution to overcome those problems by establishing a women community namely Komunitas Perempuan Singkong Jaya in 2013. The word 'Singkong' (cassava) has been used to describe the main activity of this community which is producing various food products made from cassava, such as mocaf and tapioca flour, tiwul, cassava chips etc. It could be argued that women empowerment in Desa Sukowilangun is conducted at community or group level. Schulz, Israel, Zimmerman, and Checkoway (1995) state that empowerment operates at multiple ecological levels including individuals, groups and organizations as well as the whole community. As an organization, Komunitas Perempuan Singkong Jaya has several objectives which are to avoid and reduce the domestic violence against women and children, to empower women and children, to achieve economic empowerment and gender equality, and also to deal with environmental issues. Related to these objectives, Bu Sri as the founder of this community provided more explanation as follows:

......to gather women who experienced domestic violence....so they can talk and support each other in this community.... hopefully, they will become more confident, creative and obtain knowledge, training.....as well as become powerful.... (Bu Sri: the leader of Komunitas Perempuan Singkong Jaya)

$\mathrm{Bu}$ Sri explained that Komunitas Perempuan Singkong Jaya not only had an objective to empower women in economic aspect but also to improve their capability to cope with psychological issues they suffered from domestic violence. Tiwari (2001) in Maunere and Phiri (2018) pointed out that psychological empowerment of women refers to the process by which women increase their motivation, self-interest and morals to be more involved in development programs such as education, health, agriculture etc. Bu Sri continued to explain that some of community members had traumatic experience of domestic violence. It required more patience to persuade them to get involved in community activities. Bu Sri has an expectation that the development programs of Komunitas 
Perempuan Singkong Jaya would provide various activities to its members so that they can recover from traumatic experiences and achieve economic betterment.

\section{The Development Programs of Komunitas Perempuan Singkong Jaya}

The development programs of Komunitas Perempuan Singkong Jaya have been challenged by various issues which have impeded its implementation. This study conducted a needs assessment to identify the needs of community members, as well as to reveal the issues that hinder the implementation of the programs. Needs assessment is a process to identify the needs (as well as the existing problems) and the potential of the community (Abdi, 2008). Needs assessment includes a bottom-up model which requires community participation to direct their own development programs (Larrison, 2002). In the participatory process, a decision related to development programs is made by community members who have to live with the consequences of these decisions (Onyx \& Benton, 1995). It can be argued that the community members should control their own development process which have an impact on their lives(Chambers, 1995; Ife, 2013; Kenny, 2006; Korten \& Carner, 1984).

To put control and power in the hands of community members, this study conducted a Focus Group Discussion (FGD) which involved the members of Komunitas Perempuan Singkong Jaya to identify and make decisions regarding their problems and their needs to implement the programs. Figure 3 illustrates the FGD which has been conducted with the members of Komunitas Perempuan Singkong Jaya to identify the needs and the problems of the development programs.

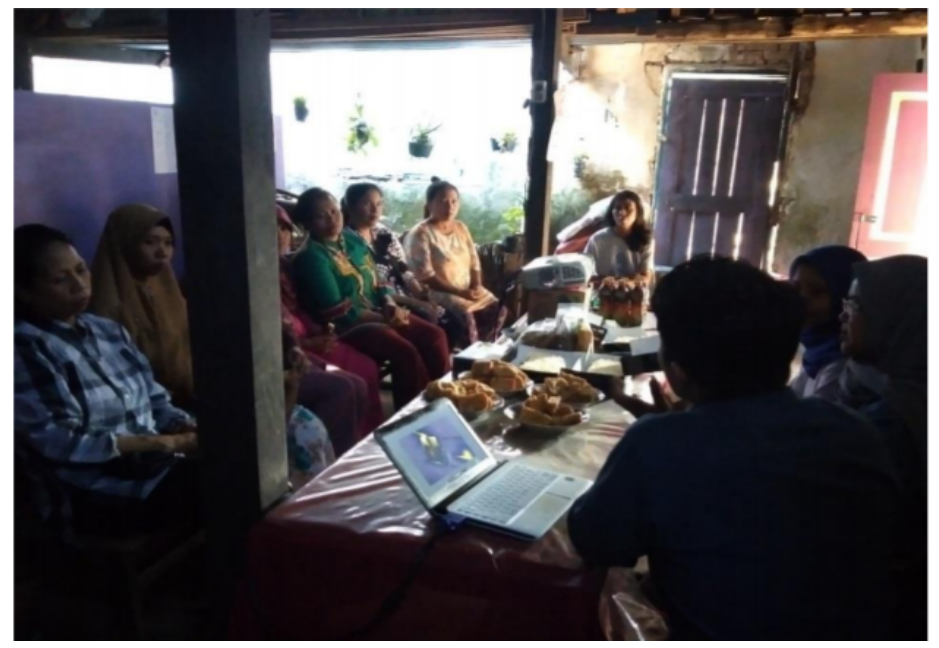

Figure 3 The Needs Assessment Process

(Source: Fieldwork Data)

From the result of the discussion, members could identify their needs and problems of their development programs as well as put them in a priority order. Figure 4 illustrates the findings of needs assessment collected from FGD, as follows:

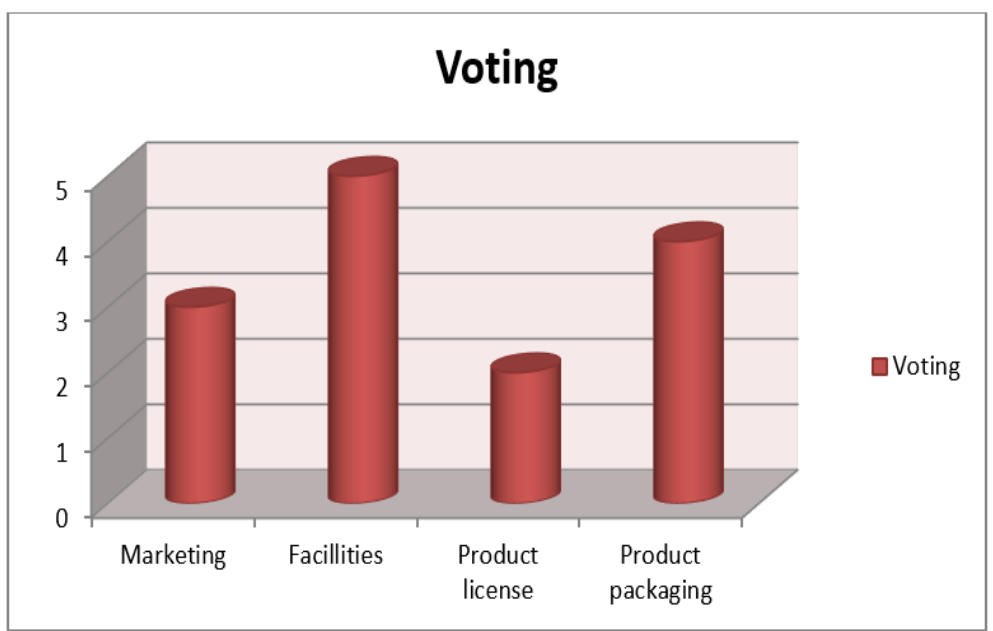


Figure 4 demonstrates several needs of Komunitas Perempuan Singkong Jaya as well as the issues faced by this community in carrying out their programs. From the discussion, the community members have also determined the priority of these needs in order. First, there is a lack of facilities to produce various products from cassava such as tiwul, mocaf flour and cassava chips. From the observation, this study found that the members of Komunitas Perempuan Singkong Jaya had to queue to use the facilities needed to produce cassava products, such as bamboo board for drying cassava, sealers and staplers for packaging process. They also utilized traditional equipment in producing the products for example firewood for cooking. As a result, cassava production was not optimal.

The second issue is related to product packaging. The members of community need assistance in designing new brands and product packaging of their products so the consumers could easily recognize them. Previous design and packaging were very simple as the community members lacked the skills and knowledge on how to make them more attractive and marketable. As a result, the community members could not obtain much profit due to the fact that the consumers had less interest to buy their cassava products. Bu Sri explained that her community members only made a small profit by selling cassava product as illustrated in the interview excerpt as follows:

.... my members sometimes complain that they could not get much profit by selling cassava products...only $R p 500 \ldots$ it's not worth it...but we don't know what we should do right now...(Bu Sri: the leader of Komunitas Perempuan Singkong Jaya)

The interview excerpt depicts the small amount of profit that the community members get by selling cassava product. For instance, they sell mocaf flour ranging from Rp $13.000-\mathrm{Rp} 18.000$. From this price, the members only receive around $\mathrm{Rp} 500$ for the profit. They complain that this profit is not worth it as they have to spend much time and energy for making mocaf flour, from peeling, washing, drying to grinding the cassava.

The third issue is product marketing. Geographical problem has hindered the community members to reach their consumers as Desa Sukowilangun is located in a remote area. They only sell their product conventionally via off-line to small shops, stalls and village markets around Desa Sukowilangun. Using this conventional marketing method, these members would need two or three months to earn some money from their cassava product. As a result, most of the community's members have side jobs to earn money for living while waiting for another income from selling their cassava product. The fourth issue is related to cassava product licensing. The members of community require license so they could sell their cassava product to a wider market.

This study also identified other problems which challenged the implementation of the community development programs. These issues include those related to the lack of capital and the lifestyle of the community members. There have been changes in the ex-migrant workers' lifestyle as they tend to become more consumptive by buying or consuming things only for prestige reasons, such as buying luxurious cars, instead of fulfilling their basic needs. This lifestyle has influenced the way the community members conducted their programs, as explained by the interviewee:

.... they used to have a lot of money from their salary as migrant workers...like high class.... bit difficult to motivate....I think it will need a long time to change it...(bu Wati: one of community's members)

The interview extract above illustrates that the lifestyle of ex-migrant workers has influenced the implementation of their programs. Ex-migrant workers need a lot of money to buy or consume various things that would give them prestige. As a result, they are reluctant to get involved in the community's program as they could not earn as much money as they used to when they became migrant workers. Moreover, ex-migrant workers have introduced the consumptive lifestyle to their families including their children. For instance, they used to send money to their children to buy luxurious items, particularly expensive cellphones or tablets. There might be some reasons why the migrant workers bought those communication devices or gadgets for their children. Besides facilitating communication with their children who were left behind, the migrant workers might assume that those gadgets could replace their absence while they were away from home to become migrant workers. This issue needs 
further investigation to find solution to this problem.

\section{The Solutions to Overcome the Problems of Development Programs}

Direct interventions have been delivered to address the problems or issues which hampered the implementation of the development programs of Komunitas Perempuan Singkong Jaya. There are different perspectives regarding the involvement of outside intervention in the community empowerment process. According to the conservative perspective, empowerment requires total selfhelp from communities or participant with minimal outside intervention (Onyx \& Benton, 1995). This point of view assumes that people who live in poverty could develop themselves, for instance by using their own latent capacity in terms of the institution of mutual support and risk sharing (Berner \& Phillips, 2005). However, in some cases, the total self-help has been challenged by several factors including internal factors namely traditional beliefs, trust in local culture, trust in community representatives, personal benefit, education and literacy (Marfo, 2008). Therefore, Marfo stated that outside intervention may be required to address these constraints as well as to stimulate civil interest in the community participation process. Adi (1994) in Adi (2008) explained that one of the roles of outside intervention is as an enabler. This enabler has a crucial role to support people to help themselves to do several things including articulating their needs, identifying their problems and developing their capacity to overcome these problems effectively.

Based on Marfo's and Adi's point of view, the direct intervention has been delivered to overcome the issues that has influenced the members of Komunitas Perempuan Singkong Jaya to participate in its development programs. As mentioned before, several issues have been identified through needs assessment process that influenced the participation of these members, including the lack of facilities and capital, skills and knowledge related to product packaging and marketing as well as product licensing. These issues have been addressed by providing some facilities to make the cassava products, giving funding to increase capital of the members and to obtain the product licensing and delivering training programs to increase capacity of the members to upgrade their product packaging as well as expanding their market. Figure 5 illustrates boards made from bamboo, one of the facilities provided for the members of communities to make their cassava products

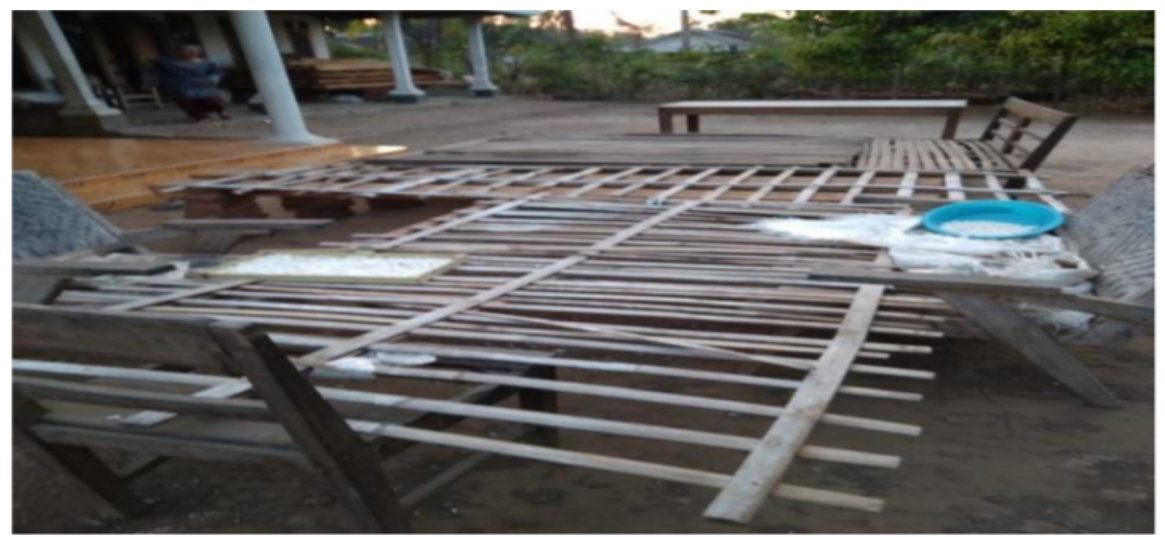

Figure 5. The Board Made from Bamboo to Dry Out the Cassava (Source: Fieldwork Data)

Figure 5 illustrates the board made from bamboo which has been utilized by the members to dry out their cassava. There were also other facilities that have been distributed to community members, namely large frying pan, gas stove, sealer for product packaging. The distribution of these facilities is expected to increase the amount of productions of the cassava product.

Through this study, funding has been distributed to overcome the lack of capital of the community members in conducting their programs. This funding is used to establish a revolving fund program by which the community members could borrow a certain amount of money or loans from this program to produce their cassava products. They have to repay their loans to Komunitas Perempuan Singkong Jaya; this community then redistributes these loans to other members, and so on. The funding has also been utilized to obtain the licensing, namely Produk Industri Rumah Tangga (PIRT) or home industry license in order to expand the market of cassava products. 
Furthermore, besides the facility and funding programs, several capacity building programs have also been provided to increase the knowledge and skills of the community members in producing their cassava product. For instance, the community members have received assistance programs to create new brand and packaging products. Figure 6 demonstrates some instance of new packaging of cassava product as follows:

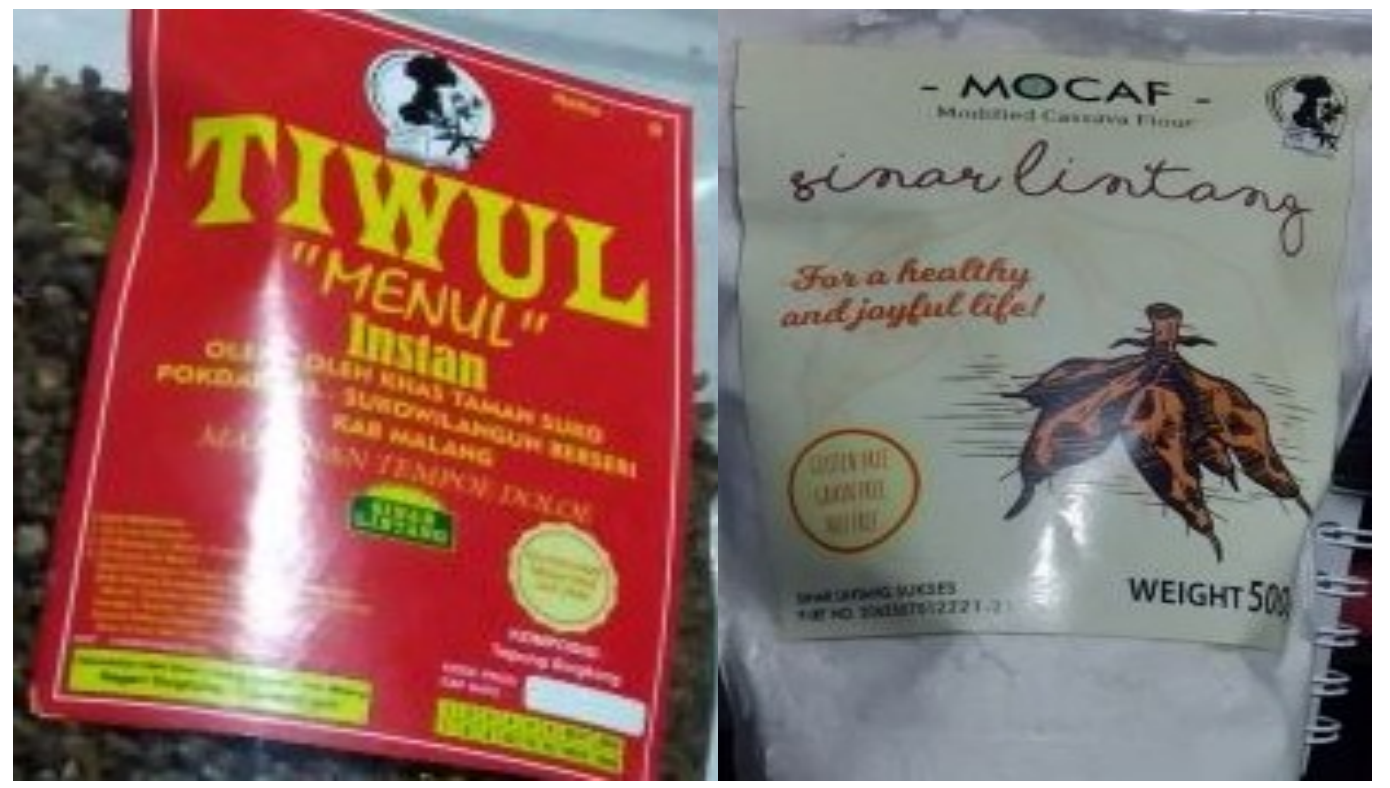

Figure 6. New Brand Designs of Cassava Products (Source: Fieldwork Data)

Figure 6 demonstrates the new brand design and packaging which have been created by the members of community. By adopting new design and packaging, it is expected that cassava products of Komunitas Perempuan Singkong Jaya could access or reach wider consumers as well as increase the price of the product to be more expensive.

Through this study, a training program has been provided to address the marketing issues by introducing two kinds of marketing methods which are via offline and online. Online product marketing has been conducted for the members of community via social media, such as Instagram, WhatsApp, Facebook and websites. These members have learnt how to make their product feature in these online media. The continuous assistance has been delivered to the members of community until they could sell their product via online independently.

In relation to the offline product marketing, a Focus Group Discussion (FGD) has been conducted to gather information related to potential locations to sell cassava products. This discussion involved other parties including youth and local elites of Desa Sukowilangun. From this discussion, new locations where the cassava product could be marketed have been mapped which are the central market of Kepanjen (capital city of Kab. Malang) and tourist destination places next to Desa Sukowilangun including Bendungan (dam) Karang Kates and Lahor. Furthermore, the discussion also offered a partnership program between Komunitas Perempuan Singkong Jaya and Badan Usaha Milik Desa (Bumdes) or Village-Owned Enterprises of Desa Sukowilangun.

It can be summed up that two kinds of development programs namely infrastructure (facilities and funding) and capacity building programs (assistance and training programs) have been delivered to Komunitas Perempuan Singkong Jaya. Related to the capacity building programs, these programs are in line with the people-centered of development perspective. This perspective puts people as the subject and primary resource who conduct the development process, and seeks to achieve the fulfilment of theirs material and spiritual well-being as the end or outcome of the development process (Korten \& Carner, 1984). Based on this perspective, some scholars pointed out that the empowerment objective could be achieved if community development practitioners focus on increasing the capacity of community members so they have power and control in designing, conducting and local community members, so they have power and control in designing, conducting and identifying problems that occur and finding solutions to these problems (Bhattacharyya, 2004; Kenny, 2006). 
This study involved the participation of members of the Komunitas Perempuan Singkong Jaya since the planning by identifying the problems through the needs assessment process as well as finding the solutions to address these problems by conducting several FGD activities. A comprehensive support and assistance were delivered to these members to undertake the development programs, from production process, packaging, finding the capital, obtaining product licensing as well as finding and expanding market to sell the cassava products. With this comprehensive assistance, it is hoped that the skills and knowledge of community members could increase, so they would have power and control to carry out their development programs independently.

\section{The Outcomes of Development Programs}

Table 1 illustrates the outputs of the development programs which have been conducted in this study, as follows:

\begin{tabular}{|c|c|c|c|}
\hline \multirow[t]{2}{*}{ No. } & \multirow{2}{*}{$\begin{array}{l}\text { The Kinds of Development } \\
\text { Program }\end{array}$} & \multicolumn{2}{|c|}{ Outputs } \\
\hline & & Before Assistance & After Assistance \\
\hline 1. & $\begin{array}{l}\text { Providing of various } \\
\text { facilities to support the } \\
\text { production of cassava } \\
\text { products }\end{array}$ & $\begin{array}{l}\text { - Cooking using firewood. } \\
\text { This would be hard in the } \\
\text { rainy season as the firewood } \\
\text { get wet and could not be } \\
\text { used for cooking } \\
\text { - Frying pan and other utilities } \\
\text { were in small size so they } \\
\text { cannot be used to produce a } \\
\text { lot of products } \\
\text { - The members of community } \\
\text { should queue to use all the } \\
\text { facilities }\end{array}$ & $\begin{array}{l}\text { - Cooking process now is } \\
\text { using gas stove so the } \\
\text { members of community } \\
\text { can cook their cassava } \\
\text { faster } \\
\text { - The members of } \\
\text { community do not need to } \\
\text { queue in using the facilities } \\
\text { - The members of } \\
\text { community can provide } \\
\text { large stocks of cassava } \\
\text { products to fulfill orders }\end{array}$ \\
\hline 2. & $\begin{array}{l}\text { Training programs to make } \\
\text { a new brand design and } \\
\text { product packaging }\end{array}$ & $\begin{array}{l}\text { The design and packaging of } \\
\text { cassava products were very } \\
\text { simple }\end{array}$ & $\begin{array}{l}\text { - The design and packaging } \\
\text { of cassava products are } \\
\text { more attractive and } \\
\text { marketable }\end{array}$ \\
\hline 3. & $\begin{array}{l}\text { The assistance for the } \\
\text { members of community to } \\
\text { access wider market to sell } \\
\text { their cassava product }\end{array}$ & $\begin{array}{l}\text { The marketing process was } \\
\text { conventional or offline to the } \\
\text { stalls, stores and local market } \\
\text { around Desa Sukowilangun }\end{array}$ & $\begin{array}{l}\text { The marketing process } \\
\text { has been conducted online } \\
\text { via WhatsApp dan Line } \\
\text { - The partnership program } \\
\text { with Bumdes is still on } \\
\text { going }\end{array}$ \\
\hline 4. & $\begin{array}{l}\text { The establishment of } \\
\text { cassava product licensing }\end{array}$ & $\begin{array}{l}\text { The members have no } \\
\text { license for their cassava } \\
\text { product }\end{array}$ & $\begin{array}{l}\text { The cassava products of } \\
\text { community's members } \\
\text { have product license of } \\
\text { PIRT }\end{array}$ \\
\hline 5. & $\begin{array}{l}\text { The establishment of } \\
\text { revolving fund program to } \\
\text { address the lack of capital } \\
\text { issue }\end{array}$ & $\begin{array}{l}\text { The members of community } \\
\text { could not maximize their } \\
\text { cassava production } \\
\text { - There are only three ex- } \\
\text { migrant workers who } \\
\text { produce cassava product } \\
\text { continuously (productive) }\end{array}$ & $\begin{array}{l}\text { - The community's } \\
\text { members could maximize } \\
\text { their cassava production } \\
\text { - } \\
\text { The number of ex-migrant } \\
\text { workers who are } \\
\text { producing cassava } \\
\text { product continuously are } \\
\text { increasing to eight } \\
\text { members (productive) }\end{array}$ \\
\hline 6. & $\begin{array}{l}\text { The assistance to motivate } \\
\text { women ex-migrant } \\
\text { workers to be involved in } \\
\text { the development programs }\end{array}$ & $\begin{array}{l}\text { The consumption-orientation } \\
\text { or lifestyle of ex-migrant } \\
\text { workers has influenced the } \\
\text { program's implementation }\end{array}$ & $\begin{array}{l}\text { The ex-migrant workers } \\
\text { are reluctant to get } \\
\text { involved in the } \\
\text { community's } \\
\text { development programs }\end{array}$ \\
\hline
\end{tabular}


Table 1 illustrates the outputs of the development programs which have been conducted on Komunitas Perempuan Singkong Jaya. Support and assistance have been provided to fulfill the needs of the members and overcome the problems that emerged in the implementation of the development programs. The assistance program has resulted in some intended outputs including the full facilities for producing of cassava products, the provision of capital and product license, as well as market expansion to sell the cassava products.

From this study, it is also found that the comprehensive assistance which has been conducted to support the implementation of development programs in a very limited way has empowered the members of Komunitas Perempuan Singkong Jaya. It can be seen from the increasing numbers of the community members (from three to eight members) who become productive by producing the cassava products independently to earn a living. This has also resulted in the increasing income of these members. Research study depicts that sustainable and comprehensive assistance model or mechanism which has been conducted by a mining industry in its CSR programs has succeeded to empower the local community. This model has increased the capacity and skills of the community to undertake development programs including their capability to make decisions in determining, conducting and finding solutions in regard to their own development programs.

However, the unintended impact of the implementation of development programs was also found. Some women ex-migrant workers are reluctant to involve in conducting these programs. The exmigrant workers have observed that they will get much money or higher income if they become migrant workers. This has also changed their life style by becoming more consumptive and having money-oriented character. As a result, women ex-migrant workers have developed an expectation of receiving much money for their participation in the community development programs. However, these ex-migrant workers find that they could not fulfill their expectation by participating in the development programs of Komunitas Perempuan Singkong Jaya. This has caused them to become resistant or reluctant to involve in these programs' implementation.

\section{CONCLUSION}

This study shows that various development programs are required to empower women, including women ex-migrant workers due to the fact that they faced various problems after arriving in their villages. One of these problems is that they become unemployed because women ex-migrant workers do not have skills and high level of education to find new jobs or occupations in their village. Other problems are related to their family problems, such as divorce and juvenile delinquency. Moreover, some of these workers experienced domestic violence while working abroad as migrant workers. This has caused traumatic experiences or other psychological issues on women ex-migrant workers.

Kelompok Perempuan Singkong Jaya is a women organization which has been established (when?) to empower women ex-migrant workers in Desa Sukowilangun. The main objective of this organization is to empower women in economic aspect and improve their capability to cope with the psychological problems they suffer from domestic violence. This study identifies various issues faced by Kelompok Perempuan Singkong Jaya in conducting their development programs, including the lack of capital and facilities to produce cassava products, product packaging issues, marketing and product licensing. During the implementation of the development programs, various support has been provided including assistance training programs and funding to overcome all those issues. Based on the concept of women empowerment, the goal of empowerment could be achieved by giving women access to land, credit and labor opportunities so that they can fight poverty issues and be equal or have power in relations to men. The findings of this study indicate that most of those supports have generated good outcomes, for instance the increasing numbers of women ex-migrant workers who can run their home industries or small businesses, such as by producing cassava product continuously and independently.

However, this study illustrates that change in the lifestyle of women ex-migrant workers, particularly the consumptive orientation has resulted in unintended impacts which is the reluctance of women exmigrant workers to be involved in the development programs. They made an 'adjustment' to this new lifestyle when they become migrant workers. This issue will require a more comprehensive and interdisciplinary strategies as the solution of the problem. 


\section{REFERENCES}

Abas, S., Widyahseno, B., \& Rudianto. (2016). Model Pemberdayaan TKI Pasca Migrasi melalui Ekonomi Produktif Menuju Keluarga Sakinah. Muaddib: Studi Kependidikan dan Keislaman, 4(1), 1-19. https://doi.org/10.24269/MUADDIB.V4I1.92

Abdi, I. R. (2008). Intervensi Komunitas: Pengembangan Masyarakat sebagai Upaya Pemberdayaan Masyarakat. Jakarta: Rajagrafindo Persada.

Adi, I. R. (1994). Psikologi, Pekerjaan Sosial dan Ilmu Kesejahteraan Sosial: Dasar-dasar Pemikiran. Jakarta: Rajawali Pers.

Adi, I. R. (2008). Intervensi Komunitas: Pengembangan Masyarakat sebagai Upaya Pemberdayaan Masyarakat. Jakarta: Rajawali Pers.

Assumptah, H., \& Suharko. (2016). Praktek Pemberdayaan Tenaga Kerja Indonesia Purna di BP3TKI (Balai Pelayanan Penempatan Perlindungan Tenaga Kerja Indonesia). Yogyakarta: Universitas Gadjah Mada.

Backhans, M. C., Lundberg, M., \& Månsdotter, A. (2007). Does increased gender equality lead to a convergence of health outcomes for men and women? A study of Swedish municipalities. Social Science and Medicine, 64(9), 1892-1903. https://doi.org/10.1016/j.socscimed.2007.01.016.

Batliwala, S. (1993). Empowerment of Women in South Asia. New Delhi: FAO.

Berner, E., \& Phillips, B. (2005). Left to their own devices? Community self-help between alternative development and neo-liberalism. Community Development Journal, 40(1), 17-29. https://doi.org/10.1093/cdj/bsi003

Bhattacharyya, J. (2004). Theorizing Community Development. Journal of the Community Development Society, 34(2), 5-34. https://doi.org/10.1080/15575330409490110.

Bungin, B. (2010). Penelitian Kualitatif: Komunikasi, Ekonomi, Kebijakan Pulbik dan Ilmu Sosial Lainnya. Jakarta: Kencana Predana Media Group.

Chambers, R. (1995). Poverty and livelihoods: whose reality counts?. ID discussion paper. Brighton: IDS.

Chawa, A. F., Al Yusainy, C., Adila, I., \& Kusumastuti, A. (2018). Deemphasize Community Development Programs on Migran Workers. Jurnal Terapan Abdimas, 3(2), 170. https://doi.org/10.25273/jta.v3i2.2807.

Dewi, N. (2019). Gaji Pekerja Migran Rp 7,6 Miliar Dikemplang, KJRI Jeddah Bicara. Tempo.Co. Retrieved from https://nasional.tempo.co/read/1232576/gaji-pekerja-migran-rp-76-miliardikemplang-kjri-jeddah-bicara.

Febrinastri, F., \& Hapsari, D. K. (2019). Sejak 2014, BNP2TKI Tempatkan 1,5 Juta Pekerja Migran Indonesia. Suara.Com. Retrieved from https://www.suara.com/news/2019/07/09/075749/sejak2014-bnp2tki-tempatkan-15-juta-pekerja-migran-indonesia.

Haggis, J., Jarrett, S., Taylor, D., \& Mayer, P. (1986). By the teeth: A critical examination of James Scott's The moral economy of the peasant. World Development, 14(12), 1435-1455. https://doi.org/10.1016/0305-750X(86)90042-2.

Hasin, F., \& Musa, H. H. (2018). Women Empowerment Model : Strategies To Overcome Challenges Research Article Special Issue. Journal of Fundamental and Applied Science, 10(July 2019), 1068-6083. https://doi.org/10.4314/jfas.v10i1s.78.

Ife, J. (2013). Community Development in an Uncertain World: Vision, Analysis and Practice. Melbourne: Cambridge University Press.

Kabeer, N. (2003). Reserved Realities: Gender Hierarchies in Development. London: Verso.

Kenny, S. (2006). Developing Communities: For the Future. Melbourne: Thomson. 
Korten, D., \& Carner, G. (1984). Planning Framework for People-Centered Development; Contributions Toward Theory and Planning Frameworks. Kumarian Press.

Koser, K., \& Laczko, F. (2010). World Migration Report. https://doi.org/10.18356/f0a20a86-en.

Lambert, V. a., \& Lambert, C. E. (2013). Qualitative Descriptive Research: An Acceptable Design. Pacific Rim International Journal of Nursing Research, 16(4), 255-256. Retrieved from http://antispam.kmutt.ac.th/index.php/PRIJNR/article/download/5805/5064.

Larrison, C. (2002). A Comparison of Top-Down and Bottom-up Community Development Intervention in Rural Mexico: Practical and Theoritical Implications for Community Development Programs. New York: Edwin Mellen Press.

Manuere, F., \& Phiri, N. (2018). A Literature Review of Women Empowerment and Development in Zimbabwe: A look at New Insights and Perspectives. Journal of Public Administration and Governance, 8(4), 57. https://doi.org/10.5296/jpag.v8i4.13818.

Marfo, E. (2008). Institutionalizing citizen participation and community representation in natural resource management: Lessons from the social responsibility agreement negotiation in Ghana. Community Development Journal, 43(4), 398-412. https://doi.org/10.1093/cdj/bsm028.

May, T. (2011). Social Research: Issues, Methods and Process (Fourt). Berkshire: McGrawHill Open University Press.

Morrison, A. R., \& Biehl, M. L. (2007). Too Close to Home: Domestic Violence in Latin America. Washington, DC: Inter-American Development Bank.

Munawaroh, K. (2019). Community E Mpowerment Model Through Optimization of The Role of Indonesian Migrant Workers (PMI ) Purna In Encouraging A Chievement Of The Sustainable Development Goal In East. Jurnal Ilmiah Administrasi Publik Dan Pembangunan, 10(1), 1926.

Nursalam, Yusuf, A., Widyawati, I. Y., \& Asmoro, C. P. (2015). Peningkatan Kemandirian Perawat Tenaga Kerja Indonesia (TKI) Yang Terinfeksi HIV Melalui Pengembangan Model Pemberdayaan Keluarga dan Peer Group Support. Jurnal Ners, 10(2), 265-271.

Octaviani, L. (2015). Pemanfataan Remitansi Ekonomi dan Sosial di Kalangan Buruh Migran Perempuan. Forum Ilmu Sosial, 42(1), 57-69.

Onyx, J., \& Benton, P. (1995). Empowerment and Ageing: Toward Honoured Places for Crones and Sages (Community; G. Craig \& M. Mayo, Eds.). New Jersey: Zed Books.

Raharto, A., \& Noveria, M. (2012). Advocacy Groups for Indonesian Women Migrant Workers Protection. Jurnal Kependudukan Indonesia, 7(1), 1-18. https://doi.org/10.14203/JKI.V7I1.80

Rahman, A. (2013). Women's Empowerment: Concept and Beyond. Global Journal Og Human Social Science. Sociology \& Culture, 13(6), 9-14. Retrieved from https://globaljournals.org/GJHSS_Volume13/2-Womens-Empowerment-Concept.pdf

Rowlands, J. (1997). Questioning Empowerment: Working With Women in Honduras. 196. Retrieved from http://books.google.co.uk/books?id=fXJKq2JQtyoC

Sandelowski, M. (2000). Focus on research methods: Whatever happened to qualitative description? Research in Nursing and Health, 23(4), 334-340. https://doi.org/10.1002/1098240x(200008)23:4<334::aid-nur9>3.0.co;2-g

Schulz, A. J., Israel, B. A., Zimmerman, M. A., \& Checkoway, B. (1995). Perceived Control at the Individual, Organizational and Community Levels The Program on Conflict Management Alternatives a t The University of Michigan. Health Education Research: Theory and Practice, 10(3), 309-327. Retrieved from https://deepblue.lib.umich.edu/bitstream/handle/2027.42/51261/495.pdf?sequence=1\&isAllowe $\mathrm{d}=\mathrm{y}$ 
Scott, J. C. (1976). The Moral Economy of the Peasant: Rebellion and Subsistence in Southeast Asia. USA: Yale University.

Siegel, M., \& Waidler, J. (2012). UNU - MERIT Working Paper Series Migration and multi dimensional poverty in Moldovan communities. Netherland.

Sitepu, A. (2011). Tindak Kekerasan Terhadap Perempuan Pekerja Migran. Informasi, Vol 16 No.(01), 15.

Sulaiman, A. I., Sugito, T., \& Sabiq, A. (2017). Komunikasi Pembangunan Partisipatif untuk Pemberdayaan Buruh Migran. Jurnal Ilmu Komunikasi, 13(2), 233. https://doi.org/10.24002/jik.v13i2.734.

Supriana, T., \& Nasution, L. (2010). The Role of Ex-Migrant Worker Enterprise Toward Local Economic Development and Factors that Influence Income of Ex-Migrant Enterprise in Sumatera Utara Province. Makara Human Behavior Studies in Asia, 14(1), 42. https://doi.org/10.7454/mssh.v14i1.571.

Sushama, S. (1998). Women and Empowerment: Approach and Strategies. Delhi: Publishing House.

Tiwari, R. S. (2001). Feminism and Globalization versus Indian Women Empowerment. New Delhi: Rawat Publication.

van den Berg, M. (2010). Household income strategies and natural disasters: Dynamic livelihoods in rural Nicaragua. Ecological Economics, 69(3), 592-602. https://doi.org/10.1016/j.ecolecon.2009.09.006

Wijayanigtyas, D. A. (2016). Pemberdayaan Tenaga Kerja Indonesia (TKI) Purna dan Keluarganya Melalui Pembentukan Sentra Usaha (Studi tentang Implementasi Pemberdayan Kelompok TKI Purna Tunas Jaya Desa Nglanggeran, Kec. Patuk, Kab. Gunungkidul, Daerah Istimewa Yogyakarta. Universitas Gadjah Mada. 